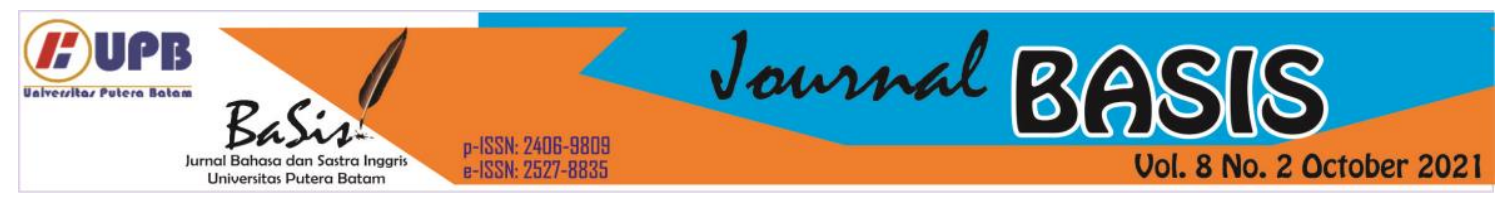

\title{
PLATFORMS, PROBLEMS AND SOLUTIONS OF ONLINE ENGLISH LANGUAGE TEACHING AT VOCATIONAL HIGH SCHOOL
}

\author{
Fajar Kristina ${ }^{1}$ \\ Bengkulu State University, Bengkulu, Indonesia \\ fajarbengkulu0@gmail.com \\ Syahrial $^{2}$ \\ Bengkulu State University, Bengkulu, Indonesia \\ syahrial@unib.ac.id \\ Wisma Yunita ${ }^{3}$ \\ Bengkulu State University, Bengkulu, Indonesia \\ wismayunita@unib.ac.id
}

\begin{abstract}
The study aimed to discover and to describe online learning platforms used, the problems faced and the solutions that offered by the English teacher in Vocational High School. The descriptive qualitative research was used as the research design in order to describe in detail the issues which had been discovered. The researcher selected 7 English teachers from each state vocational high school of Bengkulu city as the representative sample for this research. The instrument of this research was the interview guideline and data were collected by using the interview. After collecting the data, the researcher analyzed the data by using descriptive analysis. The result Google classroom and WhatsApp were effective platforms to have online English language teaching in the pandemic era, especially, for the students at the vocational high school. The problems of using the platforms were the internet connection, lack of students' motivation, lack of students' understanding, and inefficient teaching time. While the problems of teaching language skills through the use of platforms were miss understanding and lack motivation, in adequate time, lack of interaction, and overload the use of data plan. The solution that the teacher used for solving the use of platform were providing the extended time and offline module or having face to face class. However for solving the problems of teaching language skills, the teachers did Whatsapp discussion, peer feedback and having question and answer session in Whatsapp, decreasing listening activity and providing additional time for writing.
\end{abstract}

Keywords: Online English Language Teaching, Vocational High School, Platforms Used, Problems, Solutions.

\section{INTRODUCTION}

The quick transformation occurs in every aspect including the education. The government takes several decisions to minimize the spreading of the virus. One of decisions in education offers a big impact on the teaching and learning process. Especially in Indonesia, the Ministry of Education makes regulation number 15 of 2020 concerning the guidelines for organizing learning from home in an emergency for the spread of Covid-19. So, the teaching and learning 
process must be done through online learning. It has been moved fast from face-to-face or blended learning to be online learning. This condition affects many things to the teaching and learning process, especially for English language teaching. It is because the teaching of English should provide sufficient practices to the students in acquiring the skills but it cannot be offered effectively due to the Covid-19 outbreak.

The teachers also have to teach the knowledge related to the language and to give ample language input to the students. The language input requires many direct interactions to help the students be able in English (Karuppannan \& Mohammed, 2020). While the implementation of online learning provide different direct interaction between the teacher and students compared to face-to face learning. Moreover the implementation of online learning requires high needs of the use of technology in the teaching and learning process. It is showed by teachers and students have to use certain platforms to have a class during the covid-19. It cannot be ignored that the implication of online learning offers a positive effect to the teaching and learning process such as the effective and efficient time of learning (Wright, 2017).

It also can encourage the students' motivation, participation, selfconfidence, and responsibility (Muhtia, Anggri, Suparno, 2018). Furthermore, the application of online learning can help teachers be easier in preparing and offering the material as well as the students in searching and acquiring the material. It could be the one way in preparing the students to develop their $21^{\text {st }}$ - century skills such as critical thinking, problem-solving, working teams, and using digital learning devices (Ulker, 2019). The use of online learning in the pandemic era can intensify the role of the teacher as the facilitator from the elementary to university levels (Gunawan et al., 2020; Lau et al., 2020; Noah \& Gbemisola, 2020). The teachers as the controller and facilitator have to think carefully in deciding appropriate technology in supporting the teaching and learning process, especially in this emergency condition.

On the other side, the recent studies have been proved that the involving of technology give positive effect in teaching productive or receptive skills. For instance, the use of podcast for teaching listening, the study proved that podcast can increase their listening motivation and comprehension (Huriyah \& Contessa, 2020). In addition, the use of Instragram could improve the students' interaction and motivation in speaking (Devi et al., 2020). The last was the combination of synchronous and asynchronous have been proved that those combination could support each other and achieve the learning objective (Riwayatiningsih $\&$ Sulistyani, 2020). So, it can be concluded that the use of platform can support the teaching and learning process.

Zoom, Google Classroom, Google Meet are common platforms used for online teaching in pandemic-era. They are chosen because of their convenience such as they could involve many students in one meeting, share and record the meeting (Kaur et al., 2020; Noah \& Gbemisola, 2020; Tamin \& Mohamad, 2020). However, the convenience of those platforms does not make them be the favorite platforms. The use of those platforms need high consumption of internet access and high-speed internet access therefore most teachers more prefer to use 
WhatsApp and YouTube as the digital platform to support online learning in every level of education to teach English as a foreign language. (Famulasih, 2020; Gunawan et al., 2020).

Like many other schools, teaching English in vocational high school amids the Covid-19 pandemic is also done through online learning. It becomes more challenging because the English teachers have to prepare the material, teaching media, strategies which are appropriate to online learning so the students are able to use English as their soft skill to be skill full worker based on their major (Çelik et al., 2018). The implementation of online learning in teaching English for students might not run well because it happens suddenly and without enough preparation due to Covid-19.

Moreover, the involvement of technology and internet access will offer some technical problems such as the teachers do not know how to operate certain features of the platform (GillettSwan, 2017). It is caused by teachers are too busy with how to get digital material and resources then they do not focus on how to obtain the knowledge and skills about the technology (Niu, 2020).

Furthermore, the implementation of online learning also has lack of interaction between teacher and students compared with face to face class. Due to lack of interaction, feedback also cannot be given sufficiently to the student. Other problem is related to internet connection because not all of the students or teachers live where the internet can be accessed well (Erarslan, 2020). Even though, most students and teachers agree that it is an effective way to prevent the effect of the corona virus but sometimes they get bored with online learning (Mardiah, 2020). This feeling affects the students' motivation in learning English. In implementing online learning, teachers are difficult to supervise the students directly because the students probably join the class without the video. It makes the students to be undisciplined and reluctant to participate (Niu, 2020). As we know that motivation is needed as the nature of willingness in learning and acquiring English as a second or foreign language (Karuppannan \& Mohammed, 2020).

The problems above mostly find in English language teaching classes for general course. However, it might happen for English Language teaching as the vocational high school as well. The quick transformation in the English language teaching setting from face to face or blended learning to full online learning without enough preparation leads to some problems such as lack of technical competency in operating the platform, internet connection, students' motivation and lack of interaction. There are several studies that have been conducted related to the teaching and learning English amid covid-19. The first previous work showed that the process of teaching and learning English is supported more by the digital content in terms of the material and the students' tasks. The existence of digital content triggers the student motivation in learning (Hamzah et al., 2020).

However, another prior study revealed that teaching English through online learning has some barriers such as lack of facilities, lack of students and teachers' knowledge of technology, and lack of teaching strategies therefore it could not run well (Adara \& Najmudin, 2020). Moreover, the study found that the teachers have to maximize their skill, knowledge and practice to bring the teaching and learning English in online learning due to covid-19 (Atmojo \& Nugroho, 2020). So it can be 
concluded that the previous works pay more attention to the teaching and learning English through online learning in terms of barriers, materials, and teachers' knowledge of technology at university or senior high school level.

Interestingly, there is still little attention in discovering online English language teaching and learning in vocational high school, especially, concerning on the most common platform used, the problems faced and the solution to overcome the problem that happens in online learning during the covid-19 outbreak. Furthermore, the vocational high school has different purposes in teaching English as foreign language. The vocational high school more focuses on teaching English for the specific purposes based on the students' major such as hospitality, engineering, and tourism. Therefore, the teaching and learning process should provide more practices rather than giving the material to the students. So the students can achieve active communication by using English (Çelik, Stavicka, \& Odina, 2018; Muliyah \& Aminatun, 2020).

The purpose of vocational high school gives certain challenges for both and teacher in pandemic condition. Especially, teaching and learning process should be limited and should do through online learning with various personal condition of students. Meanwhile the purpose of teaching English with special purpose should be achieved in the same time. Hence, this research is conducted to discover and describe the platforms used, the problems faced and the solutions that offered by the English teacher in Vocational High School.

\section{LITERATURE REVIEW}

a) Online Teaching and Learning

The existence of online learning brings a lot of benefits for the teachers and students such as:

a. Online teaching and learning provides flexible time and place so the teaching and learning process can be done every time and in any place as long as the requirements of online class has been prepared by students and teachers (Wright, 2017).

b. The implementation of online learning can create autonomous learner. The learner could search the material by themselves then they share to others to give better understanding trough summary or video (Wang, Chen, Tai, \& Zhang, 2019

c. Teachers do not only share the knowledge easily to the students but the implementation of online learning also can motivate and engage the structure of students' learning (Haghighi, Jafarigohar, \& Khoshsima, 2019).

d. The class can be recorded therefore the students can watch the teaching and learning process more than Akhter (2020) claimed that online teaching and learning problems is raised due to the involvement of the use of internet access and technology facility. The problem can be caused by the users which are teachers or students, and the technology weaknessesone to improve their understanding (Shahzad et al., 2020).

\section{b) Teaching English for Vocational High School}

Teaching English in vocational high school is quite different from teaching English in other schools because the English should be taught to 
meet students' career related needs. Producing prospective skill full worker is one of the purpose of teaching and learning in vocational high school. This purpose requires the teachers in vocational high school including the English teachers to prepare specific material, method and strategies to teach the students.

The teaching and learning English should involve the communicative approach hence the students can use the English actively, especially for their major needs such as tourism, hospitality and accounting (Çelik, Stavicka, \& Odina, 2018; Muliyah \& Aminatun, 2020). Due to the pandemic condition, teaching English in vocational high school is implemented through online learning.

\section{c) Online Teaching and Learning Problems}

Akhter (2020) claimed that online teaching and learning problems is raised due to the involvement of the use of internet access and technology facility. The problem can be caused by the users which are teachers or students, and the technology weaknesses such as Internet Connection, Adara \& Najmudin (2020, 225) and Mulyani (2021, 197) argue that he common problem of online learning is the internet connection.

This system makes the students difficult to interact with the teacher or other students (Nartiningrum \& Nugroho, 2020; Sepulveda-escobar et al., 2020). The teacher also think that they do not enough time to prepare online teaching and learning (Setyawan, Nur, Surtikanti, \& Quinones, 2020).

\section{d) Platforms for Online Teaching and Learning}

Try, Bagata, Umamah, \& Fikri (2020) stated that the platform is any software or hardware which has some features that can be used to certain purposes such as to help the process of teaching and learning. The first platform is Whatsapp. WhatsApp gives some benefits in the teaching and learning process such as the students and teachers can share and discuss their ideas trough WhatsApp (Damanik, 2019). They also can create active interaction by sending the message in WhatsApp (Mannong, Maghfirah, Bulkis, 2020). In terms of the cost, the 20 use of WhatsApp spend fewer internet access with simple device such as smartphone (Kholis, 2020; Nuraeni $\&$ Nurmalia, 2020).

The next is zoom, this platform is used because it offers high quality of the video and audio as long as the conferencing (Nurieva \& Garaeva, 2020). The last is Submitting the task, uploading and sharing the material are the common function of Google classroom as one of online learning platform (Noah \& Gbemisola, 2020). The use of Google Classroom also can increase students' attention to the class (Sansinadi, 2020).

\section{RESEARCH METHOD}

The researcher used a descriptive qualitative research design. The researcher selected 7 English teachers from each state vocational high school of Bengkulu city as the representative sample for this research. They were chosen trough convenience sampling technique which the subjects of the research had to meet the specific criteria.

The instrument of this research was the interview guideline. This interview guideline consisted of twenty two questions comprised of three subthemes. The themes were the platform used, the problem faced and the solution used by the English teachers at state 
vocational high school of Bengkulu City.

The researcher validated the interview guideline to an expert of teaching English as a foreign language and ICT based learning to increase the validity and reliability of the instrument.

In collecting the data, the researcher did an interview by giving the question and recording the interview session. The results of interview was typed into transcript that would be analyzed for the discussion process. After got the data, the researcher analyzed the qualitative data through descriptive analysis. The descriptive analysis was done by following some steps. The first steps was the researcher tried to play the recording and made the transcript of the interview. From the transcript, the researcher classified the transcript based on the themes which were the platform used, the problem faced and the solution by the English teacher at state vocational high school of Bengkulu city. The last was the researcher compared the result of this study with some previous studies to draw the best conclusion of this research.

\section{RESULT AND DISCUSSION 4.1 Result}

The results of an interview about the platform used by the English teacher at the state vocational high school of Bengkulu city were WhatsApp and Google Classroom. The Respondents agreed that the combination between Google classroom and WhatsApp were suitable and could support each other to make an effective online English Language teaching. When the material in the form of book and video could be shared easily through Google classroom meanwhile feedback, attendant list, and online discussion could be done through the WhatsApp application.
Both of platforms were also effective for teaching and learning language skills. Based on the use of those platform above, especially, Google Classroom and WhatsApp, the researcher found that some problems happened for the online English language teaching. Most of teachers stated that the internet access and facility to have online English teaching and learning was the most problem in this case. However, other problems occurred as well for this case.

To solve the online teaching and learning problems, the English teacher in vocational high school mostly gave extended time when they were teaching and giving the task to the students. Moreover, the teacher also chose to have face to face class to solve the problem related to the students' understanding. The results also found that each of English skills has different problem Unclear instruction and motivation were the problem of reading. In the writing, the teachers found plagiarism and inadequate time as the problems of writing.

Lack of interaction, feedback and opportunity to speak were the problem of speaking class. Interestingly, all of respondents agreed that overload data plan consumption was the big problem to have listening class.

Most of teachers agreed that the motivation problem could be solve by giving the reward. Double check, punishment such as minus point, and additional time for solving the problem in teaching writing. The solution of listening problems. Most of teachers argued that they have to decrease the listening activity.

So it can be summarized that no matter what problems happen in the class, the teacher as the controller has big role to solve it with the right way. 


\subsection{Discussion}

a) The Platform

The result showed that there are two platform which were Google Classroom and Whatsapp. The Google Classroom had been chosen because most of teacher were familiar with this platform and the features inside the Google classroom could help the teacher in uploading or collecting the students' task especially in big size. Meanwhile the use of Whatsapp could support the function of Google classroom especially for the attendant list and having a discussion. It also easy to be used and both teacher and students were already accustomed with the use of Whatsapp..It is in line with the previous work found that the Google Classroom has a lot of benefit such as submitting and upload material (Noah \& Gbemisola, 2020).

However the teacher have to give clear instruction so there is no misunderstanding among students (Sukmawati \& Nensia, 2019). Moreover, the use of WhatsApp as the platform in online teaching and learning is an effective way because it only spends fewer internet access and it can be accessed using simple device (Kholis, 2020; Nuraeni \& Nurmalia, 2020). So from the discussion above, it can be concluded that the use of Google classroom and WhatsApp are appropriate thing as the most common platform used for online English language teaching and learning. It is because they can support each other and their features are convenience and suitable with the students and teacher needs. Therefore teachers and students should use it maximally. However, the teacher have to give clear instruction to avoid misunderstanding and sufficient preparation in using those platforms in online teaching and learning process.

\section{b) The Problems}

The problems in the using of platforms are data plan problem, lack of internet access, lack of facility and lack of technology knowledge. Internet access and data plan problems happen because not all of students live in the advantage area and have good facility to have the online learning.This finding is supported with the result of prior study found that the main problem of online teaching and learning is the internet connection which caused by the students do not have the internet facility or they are in disadvantage area, so they could not participate in the online learning (Adara \& Najmudin, 2020). The second problem is lack of facility like compatible smartphone or laptop. This finding is similar with the prior work proves that the second challenge of using the platform such as WhatsApp is lack facility of students. The use of platform can be useful if it is supported by sufficient facility such as smartphone or laptop (Nuraeni \& Nurmalia, 2020).

The last is lack of knowledge about the technology that can be happened both for teacher and students. The result about lack of technology knowledge is in line with the study that has been done by Prastiyo et al., (2018) finds that in the use of platform such as Google classroom, the problem of lack of knowledge technology commonly happen for the students.For the teaching English skill, the problem problem related to the reading motivation is similar with the previous work found that online English language teaching and learning without sufficient preparation makes the students get bored and lose their motivation (Mardiah, 2020).

Inadequate time is the problem that the teacher and students complained the most in the process of teaching and learning writing by using the platform. 
This problem opposites with the earlier study done by Wright (2017) that the implementation online learning give positive effects to the teaching and learning process, one of them is effective and efficient teaching and learning time. Lack of interaction as the causes of students' understanding is related to the finding of the earlier research found that in the process of online learning, the students are reluctant to participate so there is no sufficient interaction. Hence, the student did not want to make sure whether they already understood with the material or not (Nartiningrum \& Nugroho, 2020).

The problem of the listening activity is supported by the result of prior work proves that online teaching and learning cause limited access for the audio of listening. it is in line with prior work proved that the students do not have same listening background and experience therefore it makes the teacher have to think creatively (Utomo et al., 2019).

\section{c) Solution}

The solution to have face to face class in order to make blended learning class is supported by the finding of prior research claim that the combination of face to face and online learning class known as blended learning. The implementation of blended learning has function to give sufficient practice, feedback and autonomous learning (Nuraeni, 2019; Sanu \& Samarinda, 2019).For the ineffective teaching time, offering the extended time was the correct way to solve this problem. Besides, two ways above, one of teacher tried to give a module for the students so they can learn and practice through the module. The ideas of teacher in providing the module is related to the previous work about one of teacher competence in teaching English as a foreign language. It is known as strategic competence which pushes the teacher to think and to act creatively in solving the problems. The problems of teaching and learning can be in the form of language problems, technical problem or material problems (Alseghayer, 2017).

To overcome lack of students' motivation, the teacher took intensive control by using WhatsApp application is in line with the study proved that the teacher have to use the role as the facilitator maximally in the process of online teaching and learning (Gunawan, Suranti, \& Fathoroni, 2020; Lau, Yen, \& Mohamad, 2020; Noah \& Gbemisola, 2020).While for teaching the writing where the most problem is related to the time. The teachers offer additional time much more than the face to face class. The teacher action in providing the additional time for online writing activity is contrast with the result of previous study found that Online teaching and learning provides flexible time and place so the teaching and learning process can be done every time and in any place as long as the requirements of online class has been prepared by students and teachers (Wright, 2017).

Next solution is providing communication activity such as question and answer to overcome lack of interaction. Providing question and answer to make the students want to give interaction in speaking activity is supported by the previous study done by Cheung, (2021) found that the students need sufficient triggers for giving the interaction such as providing question and answer session or quiz.

The last solution is given to overcome the problem of listening activity. The finding shows that the teachers in vocational high school choose to decrease the listening activity. 
In decreasing the listening activity, the teacher have to think carefully because the students do not have same level of listening activity. The fact of students do not have same level of listening is in line with the previous study argued that not only speaking, in the listening activity, the students do not have same listening background and experience therefore it makes the teacher have to think creatively to decide and to offer appropriate activity for the students (Utomo et al., 2019).

The discussion above also proves that how important the role of teaching in online teaching and learning. Therefore, the teacher have to prepare online teaching and learning well in terms of technology knowledge and teacher's competence.

\section{CONCLUSION}

Google classroom and WhatsApp were effective platforms to have online English language teaching in the pandemic era, especially, for the students at the vocational high school. The use of both platforms could support each other. However, clear instruction was needed to avoid miss understanding in the process of the teaching and learning.

The problems of using the platforms were the internet connection, lack of students' motivation, lack of students' understanding, and inefficient teaching time. While the problems of teaching language skills through the use of platforms were miss understanding and lack motivation for the reading skill, in adequate time for the writing skill, lack of interaction for the speaking skill, and overload the use of data plan for the listening.

The solution that the teacher used for solving the use of platform were providing the extended time and offline module or having face to face class.
However for solving the problems of teaching language skill, the teachers did Whatsapp discussion for reading, peer feedback and having question and answer session in Whatsapp for speaking, decreasing listening activity and providing additional time for writing. From those solutions, the process of online teaching and learning depended on the role of the teacher as the facilitator of learning. The problems and the condition of online learning cannot be avoided but it should be faced with a good and appropriate strategy.

\section{REFERENCES}

Adara, R. A., \& Najmudin, O. (2020). Analysis on the Differences in EFL Learners' Demotivating Factors After Covid 19 Pandemic. Ta'dib, 23(2), 225. https://doi.org/10.31958/jt.v23i2.2 373

Al-seghayer, K. (2017). The Central Characteristics of Successful ESL / EFL Teachers. Journal of Language Teaching and Research, 8(5), 881-890. https://doi.org/http://dx.doi.org/10. 17507/jltr.0805.06

Atmojo, A. E. P., \& Nugroho, A. (2020). EFL Classes Must Go Online! Teaching Activities and Challenges during COVID-19 Pandemic in Indonesia. Register Journal, 13(1), 49-76. https://doi.org/10.18326/rgt.v13i1. 49-76

Çelik, S., Stavicka, A., \& Odina, I. (2018). Are We Really Teaching English for Specific Purposes, or Basic English Skills? The Cases of Turkey and Latvia. Springer International Publishing Switzerland, 243-264.

Cheung, A. (2021). Language Teaching during a Pandemic: A Case Study 
of Zoom Use by a Secondary ESL Teacher in Hong Kong. RELC Journal.

https://doi.org/10.1177/003368822 0981784

Devi, P., Virgiana, B., \& Auli, M. (2020). Instagram: How Do Students View on It in Speaking Classroom. Jurnal Basis, 7(2), 351. https://doi.org/10.33884/basisupb.v $7 \mathrm{i} 2.2435$

Erarslan, A. (2020). Online Learning Experiences of University Students in ELT and the Effects of Online Learning on their Learning Practices Language and Technology, 2(April), 44-58.

Famulasih, S. (2020). Students , Experiences in Using Online Learning Applications Due to COVID-19 in English Classroom. Studies in Learninng and Teaching, 1(2), 112-121. https://doi.org/https://doi.org/10.46 627/silet INTRODUCTION

Gillett-Swan, J. (2017). The Challenges of Online Learning: Supporting and Engaging the Isolated Learner. Journal of Learning Design, 10(1), 20.

https://doi.org/10.5204/jld.v9i3.29 3

Gunawan, Suranti, Y., \& Fathoroni. (2020). Variations of Models and Learning Platform for Prosepective Teachers During the Covid -19 Pandemic Period. Indonesian Journal of Teacher Education, 1(2), 61-70.

Hamzah, A., Januarty, R., \& Wira, A. (2020). Digital Content for Millennial Gemerations: Teaching the English Foreign Language Learner on Covid-19 Pandemic. Journal of Southwest Jiatong University, 55(3), 1-12. https://doi.org/DOI: https://doi.org/10.1017/S02660784
16000407

Huriyah, S., \& Contessa, E. (2020). Podcast With Peer Assisted Learning To Develop Efl Learners Listening Comprehension and Motivation. Jurnal Basis, 7(2), 363.

https://doi.org/10.33884/basisupb.v $7 \mathrm{i} 2.2476$

Karuppannan, S., \& Mohammed, L. A. (2020). Predictive Factors Associated with Online Learning during Covid-19 Pandemic in Malaysia: A conceptual Framework. 4(4), 19-29.

Kaur, C., Singh, S., Abdullah, N. Y., Moneyam, S., Of, V., \& Scaffolding, T. (2020). $R$, Rethinking English Language Teaching Through Telegram, Whatsapp, Google. September.

Lau, E., Yen, Y., \& Mohamad, M. (2020). Utilising E-Learning to Assist Primary School ESL Pupils in Learning to Spell during COVID-19 Pandemic: A Literature Review. 1223-1230. https://doi.org/10.4236/ce.2020.11 8091

Mardiah, H. (2020). The Use of ELearning to Teach English in the Time of the Covid-19 Pandemic. 1(2), 49-55.

Muhtia, Anggri, Suparno, S. (2018). Blended Learning Using Schoology as An Online Learning Platform. 2nd English Language and Literature International Conference (ELLiC), 2, 171-175.

Niu, J. (2020). Exploration Into College English Teaching Practice During the Period of Pandemic Prevention and Control. 480(Mmet), 575-578.

Noah, O., \& Gbemisola, O. (2020). Impact of Google Classroom as an Online Learning Delivery during COVID-19 Pandemic: The Case of 
a Secondary School in Nigeria. 33(9), 53-61. https://doi.org/10.9734/JESBS/202 0/v33i930259

Nuraeni, C., \& Nurmalia, L. (2020). Utilizing WhatsApp Application in English Language Learning Classroom. Metathesis: Journal of English Language, Literature, and Teaching, $\quad 4(1), \quad 89$. https://doi.org/10.31002/metathesis .$v 4 i 1.2289$

Prastiyo, W., Djohar, A., \& Purnawan, P. (2018). Development of Youtube integrated google classroom based e-learning media for the light-weight vehicle engineering vocational high school. Jurnal Pendidikan Vokasi, $8(1)$, 53. https://doi.org/10.21831/jpv.v8i1.1 7356

Riwayatiningsih, R., \& Sulistyani, S. (2020). the Implementation of Synchronous and Asynchronous ELanguage Learning in Efl Setting: a Case Study. Jurnal Basis, 7(2), 309.

https://doi.org/10.33884/basisupb.v $7 \mathrm{i} 2.2484$

Tamin, N. H., \& Mohamad, M. (2020). Google Classroom for Teaching and Learning in Malaysia Primary School during Movement Control Order ( $\mathrm{MCO}$ ) due to Covid - 19 Pandemic: A Literature Review. 3(5), 34-37.

Ulker, U. (2019). Reading Activities in Blended Learning : Recommendations for University Language Preparatory Course Teachers. International Journal of Social Sciences \& Educational Studies, 5(3), 83-94. https://doi.org/10.23918/ijsses.v5i3 p83

Utomo, S., Kusmaryati, S. E., \& Sulistyowati, T. (2019). The
Challenges and Difficulties in Teaching Listening: An Exploratory Research in a Junior High School in Kudus. Language Circle: Journal of Language and Literature, 14(1), 27-38. https://doi.org/10.15294/lc.v14i1.1 9471

Wright, B. M. (2017). Blended Learning: Students Perception of Face to Face and Online EFL Lessons. International Journal of Applied Linguistics, 7(1), 64-71. https://doi.org/dx.doi.org/10.17509 /ijal.v7i1.6859 
